\title{
Serum Vascular Endothelial Growth Factor VEGF and Interlukin-8 As a Novel Biomarkers For Early Detection of Ovarian Tumors
}

\author{
Maisaa G. Jumaa* \\ Khalid A. Habib** \\ Munther J. Hussein**
}

Received 7, August, 2013

Accepted 30, October, 2013

\section{(i) 9}

This work is licensed under a Creative Commons Attribution-NonCommercialNoDerivatives 4.0 International Licens

\section{Abstract:}

Epithelial ovarian cancer is the leading cause of cancer deaths from gynecological malignancies. Angiogenesis is considered essential for tumor growth and the development of metastases. VEGF and IL -8 are potent angiostimulatory molecules and their expression has been demonstrated in many solid tumors, including ovarian cancer.

VEGF and IL-8 concentrations were measured by ELISA test (HumanVEGF,IL-8). Bioassay ELISA/ US Biological / USA).

The median VEGF and IL-8 levels were significantly higher in the sera of ovarian cancer patients than in those with benign tumors and in healthy controls.

Pretreatment VEGF and IL-8 serum levels might be regarded as an additional tool in the differentiation of ovarian tumors.

Key words: Ovarian cancer, VEGF, IL8, Serum

\section{Introduction:}

Ovarian cancer represents the fourth most frequent type of cancer among females and is the leading cause of death from gynecological cancer in the western world. It is often cause more deaths in the United States than any other type of female reproductive tract cancer, with an estimated 22,430 new cases and 15,280 deaths in 2007 [1]. Approximately $90 \%$ of primary malignant ovarian tumors are epithelial (carcinomas), and are thought by most investigators to arise from the ovarian surface epithelium (OSE) or more likely from surface epithelial inclusion cysts [2,3]. Approximately $70 \%$ of ovarian cancers are diagnosed at advanced stage and only 30\% of women with such cancers can expect to survive 5 years. While fewer than $20 \%$ of ovarian cancers are confined to the ovaries at diagnosis, the five-year survival of women with localized tumors exceeds 90\%. Effective screening methods have impacted on survival in breast and cervical cancer, but at present there is no effective screening test for ovarian cancer. Simultaneous evaluation of multiple markers may increase the sensitivity while maintaining high specificity[4]. Tumor angiogenesis is a critical step in the progression of cancer, including melanoma, allowing tumors to grow beyond 1-2 $\mathrm{mm}$ in diameter. The expression of VEGF, interleukin (IL)-8 have been shown to be important for this process $[5,6]$.On the other hand these novel markers in combination with CA125 were able to achieve a sensitivity of $88 \%$ and a specificity of $98 \%$ in early-stage ovarian cancer serum samples. VEGF may prove to be a complementary marker to CA125, as

*Misan University, College of Medicine.

**University of Baghdad College of Science for women Biology Department

*** Institute of Liver Studies, King's College Hospital, London 293 
has been shown in studies by Gorelik et al. [7]. Postoperative VEGF levels were significantly lower in comparison to preoperative levels, while significantly elevated values were seen in patients with metastasis as compared to patients lacking metastasis[8]. This may be compared clinically in the near future as the latest randomized trial for advanced stage ovarian cancer in the US, incorporating anti-VEGF therapy with standard cytotoxic agents.

IL-8 derived from macrophages/monocytes had an angiogenic effect in rat cornea models and could induce proliferation and chemotaxis of human umbilical vein endothelial cells[9]. The angiogenic activity in condition medium of cultured macrophages isolated from rheumatoid synovial tissue can be blocked by either IL- 8 neutralizing antibodies or IL-8 antisense oligonucleotide. The involvement of IL-8 in tumor angiogenesis was first demonstrated by Smith et al, [10], who showed that IL-8 was overexpressed in the cancer cells of bronchogenic carcinoma.

Recent studies have shown that IL8 was constitutively expressed in several human cancer cell lines derived from astrocytoma, hepatoma, transitional cell carcinoma, and melanoma, and is associated with angiogenesis and metastatic potential in human melanoma cell lines in a nude mice model [11].

The aim of this study was to determine the serum levels of VEGF and IL-8 in healthy individual, patients with benign tumors and patients with malignant ovarian tumors and evaluate the ability of using this marker for early detection of ovarian cancer.

\section{Materials and Methods:}

The serum samples from 60 patients diagnosed with different types and stages of ovarian cancer, 15 patients with benign ovarian tumors, and 15 healthy controls were tested. Serum samples from patients with early-stage ovarian cancer, and women with benign pelvic disease, were provided by certain Iraqi hospitals (AlKadhemia , AL - Yarmouk Teaching Hospital and Baghdad Hospital, the Teaching Laboratories of Medical City, Nuclear Medical Hospital in Baghdad and Alsader Hospital in Missan). All the patients had provided their medical history and had undergone clinical and ultrasound examination of the pelvic organs before they were qualified for the study. The average age of this group was 45.8 years and the range was $10-$ 80 years. The blood sample was dispensed in a plain tube, and left for 20 minutes at room temperature (20 $25^{\circ} \mathrm{C}$ ) for clotting. Then, it was centrifuged at $3000 \mathrm{rpm}$ for 10 minutes to collect serum. The serum was divided into aliquots $(0.3 \mathrm{ml})$ and stored in the freezer $\left(-20^{\circ} \mathrm{C}\right)$ until use. Proangiogenic factor levels were determined by ELISA using (US Biological / USA) according to the recommendations of the manufacturer. The kits were designed to measure human VEGF-A and IL-8 levels in cell culture, supernatant, serum, and plasma. The method's sensitivity for VEGF-A165 was $9 \mathrm{pg} / \mathrm{ml}$, with reference values in the serum of 16$1000 \mathrm{pg} / \mathrm{ml}$. The method's sensitivity for IL-8 was 4-10 $\mathrm{pg} / \mathrm{ml}$, with reference values in the serum $(50-1600$ $\mathrm{pg} / \mathrm{ml}$ ). Concentrations were measured by a Micro ELISA system/ Biotest/Germany with wavelength $405 \mathrm{~nm}$ and 450nm for VEGF and IL8 respectively.

\section{Statistical Analysis}

The Statistical Analysis SystemSAS (2010) was used to effect of difference factors in study parameters or percentage. The least significant 
difference -LSD test used to the comparative between means in this study.

\section{Results:}

Analysis of the present study was performed on the following parameters: type of ovarian cancer (Epithelial tumors, Sex cord-stromal tumors ,Germ cell tumor), histopathological subtypes of epithelial ovarian tumors(Serous tumors, Mucinous tumors, Endometroid tumors, Clear cell tumors, and burnner tumors) and FIGO stages (I,II,III). The results showed that ovarian cancer patients had highly significant levels of VEGF (Mean \pm SE :236.59pg/ml \pm 33.18 , $p$ value $=0.0001<0.01$ ), and IL-8 (Mean \pm SE $: 241.85 \mathrm{pg} / \mathrm{ml} \pm 32.06, \mathrm{p}$ value $=0.0003<0.01)$, compared to those of patients with benign ovarian tumor or healthy individuals. There were no statistically significant differences in both proangiogenic factors concentrations in the blood serum for clinical stages I/II and III ovarian cancer. Significant differences in the proangiogenic factors concentrations were observed between

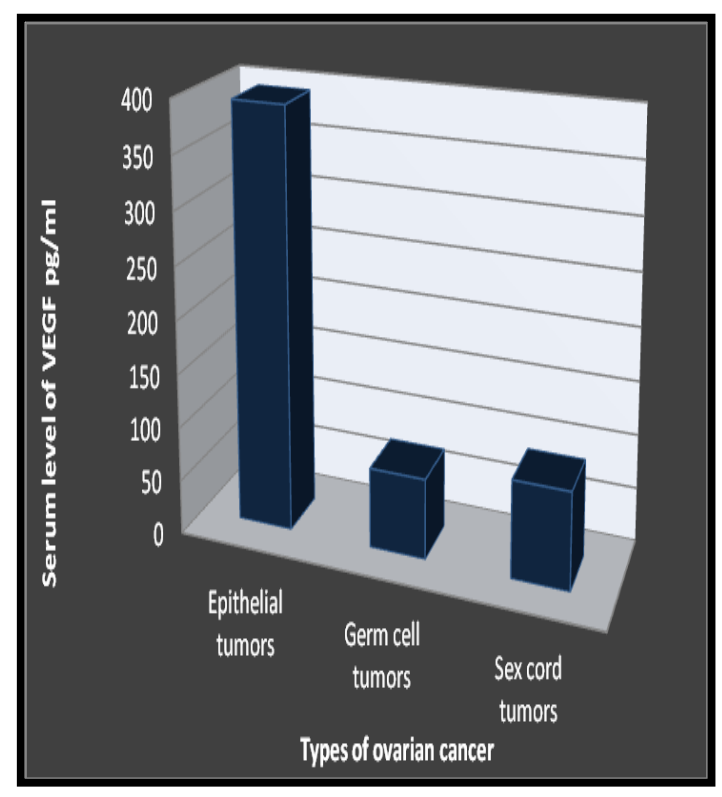

Fig.(1): The serum level of VEGF in the three types of ovarian cancer. The epithelial ovarian tumors were associated with the highest level of VEGF the three pathological types of ovarian cancer. The patients with epithelial ovarian cancer showed the highest level of $\operatorname{VEGF}(393.27 \mathrm{pg} / \mathrm{ml})$ (figure1), while for IL-8 Germ cell tumors were statically significantly higher (Mean \pm $\mathrm{SE}: 291.65 \pm 0.00, \mathrm{P}$ value $=0.00016<0.01$ ) (figure2) than the patients with epithelial ovarian tumors (mean: 291.65 and $193.43 \mathrm{pg} / \mathrm{ml}$ ). and sex-cord tumors(Mean \pm SE: $137.03 \pm$ 74.14). Statistically significant differences were observed between different pathological subtypes of epithelial ovarian tumors. Patients with serous adenocarcinoma showed the highest level of VEGF(Mean \pm SE: $323.25 \mathrm{pg} / \mathrm{ml} \quad \pm \quad 71.86, \quad p$ value $=0.034<0.5$ ) (figure 3 ), while Patients with endometrial tumors showed the highest level of IL-8 (Mean $\pm \mathrm{SE}: 408.59 \mathrm{pg} / \mathrm{ml} \pm 188.40, \mathrm{p}$ value $=0.0549<0.5$ ) (figure4). These data suggest that VEGF and IL-8 may be a useful serological biomarkers for clinical diagnosis and prognosis of ovarian cancer, for follow-up of ovarian tumor metastasis and for monitoring the efficacy of therapy in patients with ovarian carcinomas.

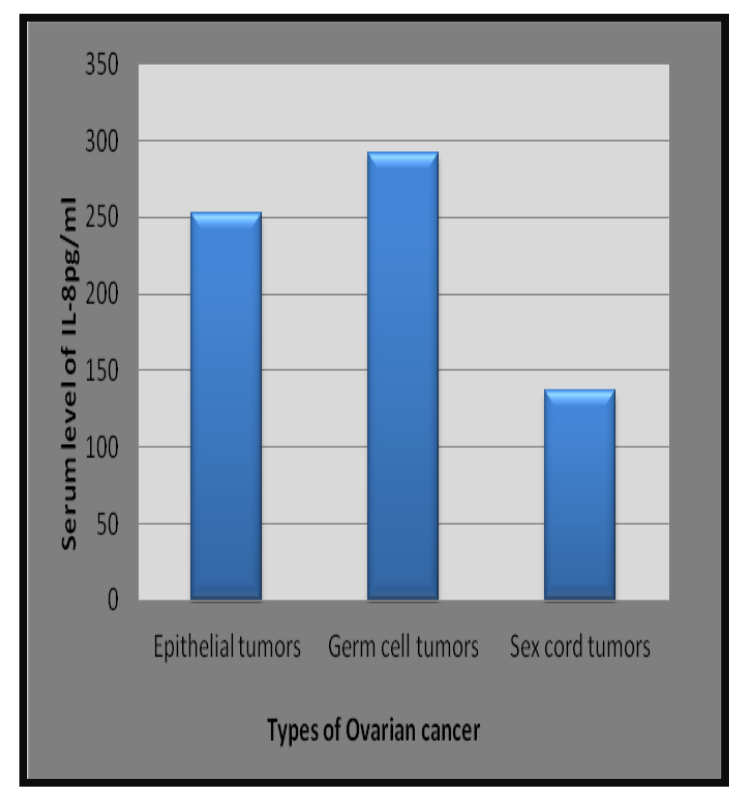

Fig.(2): The serum level of IL-8 in the three types of ovarian cancer. The Germ cell tumors were associated with the highest level of IL-8 


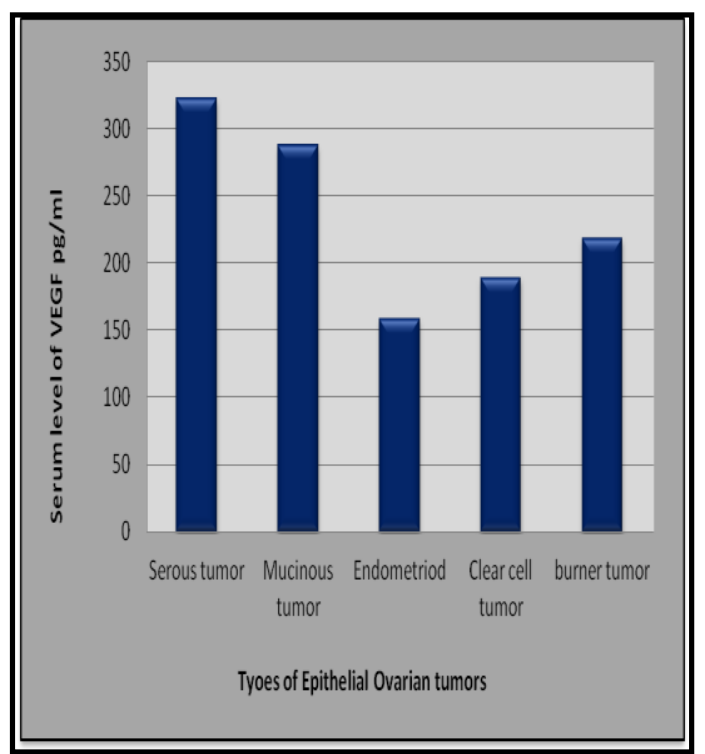

Fig. (3):The mean serum levels of VEGF in the different Epithelial ovarian tumor types. the serous tumors showed highest level as compared with other epithelial ovarian tumor types.

\section{Discussion:}

The present study showed that there were statistically significantly higher serum VEGF levels in the patients with ovarian cancer (Mean: $236.59 \mathrm{pg} / \mathrm{ml}$ ) than in the patients with benign ovarian tumors and healthy controls(Mean: $25.92 \mathrm{pg} / \mathrm{ml}, \quad 0.464$ $\mathrm{pg} / \mathrm{ml}$ ). These results confirm those presented in other studies including Sadlecki et al.,2009 [12],who found that statistically significantly higher serum of VEGF levels in the patients with ovarian cancer than in the patients with benign ovarian tumors and the control group (459.15 vs. 131.80 $\mathrm{pg} / \mathrm{ml}$ ), the same results were reported by other instigators $[13,14,7]$.

In the present study, VEGF levels were analyzed in relation to tumor clinical stage which showed that no statistically significant differences in proangiogenic factor concentrations in the blood serum for clinical stages I/II and III/IV ovarian cancer, the same results were confirmed by Sadlecki $e t$ al.,2009 and Duncan et al.,2008 $[12,15]$ who showed that the VEGF levels did not correlate with any of the

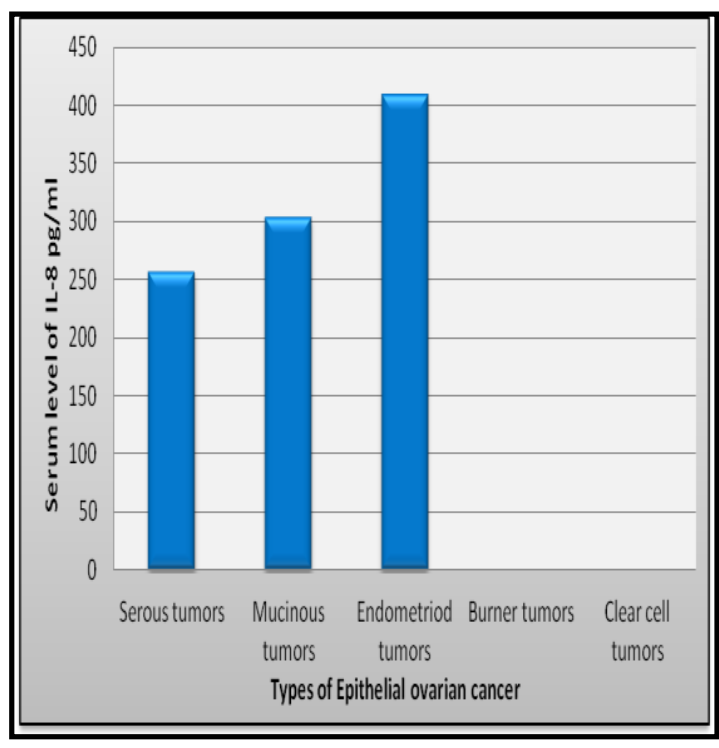

Fig. (4):The mean serum levels of IL-8 in the different Epithelial ovarian tumor types. the Endometriod tumors showed highest level as compared with other epithelial ovarian tumor types, while the mean serum level of IL-8 in Burner tumors and Clear cell tumors was $0 \mathrm{pg} / \mathrm{ml}$

established clinic pathologic prognostic variables e.g., age, stage, and grade.

In relation with histological type our study showed that the highest level of VEGF was detected in patients with serous ovarian tumors followed by mucinous tumors and endometriod tumors, these results were differ from that reported by Yamamoto et al.,1997 [16]who showed that elevated level of VEGF was found in the fluid of mucinous tumors, but not in the serous tumors. Sadlecki et al.,2009 [12],who showed that no statistically significant differences in VEGF concentrations were observed between histological differentiation of ovarian cancer. VEGF plays a significant part in the normal function of the ovary, with serum VEGF levels rising and falling in a predictable pattern during the ovulatory cycle[17].Therefore, it is not surprising that VEGF plays a role in the biology of ovarian cancer. The result of our study and these obtained from other studies proved that VEGF plays a major role in ovarian cancer progression not only due to its pro angiogenic properties, but also due to 
its ability to increase vessel permeability, leading to the presence of peritoneal fluid, which promotes the intra peritoneal dissemination of ovarian cancer. Measuring VEGF in peritoneal fluid might be useful in the differential diagnosis of ovarian tumors, but not in examining residual or recurrent disease[18]. The strong association between tumor angiogenesis, VEGF expression and serum levels, and clinical outcome in ovarian cancer makes the VEGF pathway an attractive therapeutic target.

Recently, it has been shown that IL-8 plays a critical role in cancer invasion, angiogenesis and metastasis[19,20], and is considered as an important component of tumor microenvironment $[21,22]$. The results of the present study showed that the serum IL-8 levels was statistically significantly higher in the patients with ovarian cancer $(241.85 \mathrm{pg} / \mathrm{ml})$ than in those with benign tumors and in the control group $(16.89 \quad \mathrm{pg} / \mathrm{ml}$, $44.07 \mathrm{pg} / \mathrm{ml}$ ).Our result are identical with those obtained from other studies that performed by Sadlecki et al.,2009 [12] who reported that the serum IL-8 levels were statistically significantly higher in the patients $(24 \mathrm{pg} / \mathrm{ml})$ with ovarian cancer than in those with benign tumors and in the control group $(10.5 \mathrm{pg} / \mathrm{ml}, 8.20 \mathrm{pg} / \mathrm{ml})$. Gorelik et al.,2005 [7]showed that the serum concentrations of certain biomarkers including IL-8 were significantly higher in ovarian cancer patients (24 $\mathrm{pg} / \mathrm{ml}$ ) as compared with benign tumors and healthy controls $(12.4 \mathrm{pg} / \mathrm{ml}, 10.2 \mathrm{pg} / \mathrm{ml})$.Our results showed that there were no statistically significant differences in proangiogenic factor concentrations in the blood serum for clinical stages I/II and III of ovarian cancer, these results identical with those reported by [12] and [23], in which they indicated other studies that no significant correlation between IL- 8 ascites levels and FIGO stage in ovarian cancer patients.

We found in this study a significant differences in IL-8 concentrations between different subtypes of ovarian cancer, patients with endometriod tumors showed the highest serum level of IL-8 followed by mucinous, and serous tumors, these results are similar to that reported by Greg et al., 2008 [24]who found IL-8 was over expressed in endometrioid, mucinous, and serous ovarian cancer while its differ from that reported by others $[12,23,25]$, who found that no significant correlation between IL-8 ascites levels and histopathology of ovarian cancer patients.

Analysis of reference data and the results of the present study suggest that IL-8 is a very important factor in tumor angiogenesis. As IL-8 level was high in ovarian cancer patients so $\mathrm{IL}-8$ serum levels might be regarded as an additional tool in the differentiation of ovarian tumors. Evaluation of $\mathrm{IL}-8$ levels in blood serum may also be helpful in diagnostics and in monitoring malignant ovarian tumor therapy and it also may represent a promising target for the development of adjuvant therapy for ovarian cancer.

\section{References:}

1. Jemal A.; Siegel R.; Ward E.; Murray T.; Xu J.; Thun M.J. Cancer statistics. CA Cancer J Clin ;57:43-66.

2. Feeley K.M. and Wells M. 2001. Precursor lesions of ovarian epithelial malignancy. Histopathology; 38:87-95.

3. Bell D.A. 2005.Origins and molecular pathology of ovarian cancer. Mod Pathol;18:S19-S32.

4. Das R.M. and Bast R.C., Jr. 2008. Early detection of ovarian 
cancer. Biomark Med. June; 2(3): 291-303.

5. Nilsson M.B.; Langley R.R.; Fidler I.J. 2005.Interleukin-6, Secreted by Human Ovarian Carcinoma Cells, Is a Potent Proangiogenic Cytokine. Cancer Res;65:10794-10800.

6. Tammela T; Enholm B; Alitalo K; Paavonen K. 2005. The biology of vascular endothelial growth factors. Cardiovascular Research; 65:550-563.

7. Gorelik E; Landsittel DP; Marrangoni AM. 2005. Multiplexed immunobead-based cytokine profiling for early detection of ovarian cancer. Cancer Epidemiol Biomarkers Prev;14:981-987.

8. Li L; Wang L.; Zhang W. 2004. Correlation of serum VEGF levels with clinical stage, therapy efficacy, tumor metastasis and patient survival in ovarian cancer, Anticancer Research, vol. 24, no. 3B, pp. 1973-1979.

9. Koch, A. E.; P. J. Polverini; S. L. Kunkel; L. A. Harlow; L. A. Dipietro; V. M. Elner; S. G. Elner and R. M. Strieter. 1992. Interleukin-8 as a macrophagederived mediator of angiogenesis. Science 258, 1798-17801.

10. Smith L.H.; Morris C.R.; Yasmeen S.; Parikh-Patel A.; Cress R.D.; Romano P.S. 2005. Ovarian cancer: can we make the clinical diagnosis earlier? Cancer.; 104:1398-1407.

11. Singh R. K.; M. Gutman and R. Radinsky.1994. Expression of interleukin-8 correlates with the metastatic potential of human melanoma cells in nude mice. Cancer Res 54, 3242-3247.

12. Sadlecki P.; Szymnski M., Szymnski W. 2009. Serum Vascular Endothelial Growth Factor and Interleukin-8 Levels in Epithelial Ovarian Tumors. Adv Clin Exp Med:18, 2, 135140.

13. Cooper BC; Ritchie JM; Broghammer CL; Coffin J; Sorosky JI; Buller RE; Hendrix MJ; Sood AK .2002. Preoperative serum vascular endothelial growth factor levels: significance in ovarian cancer. Clin Cancer Res, 8, 3193-3197.

14. Demirkiran F; Kumbak B; Bese $\mathrm{T}$; Arvas M; Benian A; Aydin S; Uzun H; Sanioglu C; Aydinli K; Kosebay D. 2003. Vascular endothelial growth factor in adnexal masses. Int $\mathrm{J}$ Gynaecol Obstet , 83, 53-58.

15. Duncan T.J.; Al-Attar A.; Rolland P.; Scott L.V.; Deen S.; Liu D.T.Y.; Spendlove L.; and Durrant L.G. 2008. Vascular Endothelial Growth Factor Expression in Ovarian Cancer: A Model for Targeted Use of Novel Therapies? Clin Cancer Res, 14:3030-3035.

16. Yamamoto S.; Konishil I.; Mandal M.; Kuroda H.; Komatsu T.; Nanbul K.; Sakahara H. and Mori T. 1997.Expression of vascular endothelial growth factor (VEGF) in epithelial ovarian neoplasms: correlation with clinicopathology and patient survival, and analysis of serum VEGF levels. British Joumal of Cancer: 76(9), 12211227.

17. Ramakrishnan S.; Subramanian I.V.; Yokoyama Y. 2005. Angiogenesis in normal and neoplastic ovaries. Angiogenesis.; 8(2):169-182.

18. Chechlinska M; Kaminska J; Markowska J; Kramar A; Steffen J. 2007. Peritoneal fluid cytokines and the differential diagnosis of benign and malignant ovarian tumors and residual/recurrent 
disease examination. Int $\mathrm{J}$ Biol Markers, 22 (3), 172-180.

19. Iguchi H; Ono M; Matsushima K; Kuwano M. 2000.Overproduction of IL-8 results in suppression of bone metastasis by lung cancer cells in vivo. Int J Oncol; 17: 329333.

20. Kozłowski L; Zakrzewska I; Tokajuk P; Wojtukiewicz MZ. 2003. Concentration of interleukin-6 (IL-6), interleukin-8 (IL-8) and interleukin-10 (IL-10) in blood serum of breast cancer patients. Rocz Akad Med Bialymst; 48: 82-84.

21. Kogan-Sakin I.; Cohen M.; Paland N.; Madar S.; Solomon H.; Molchadsky A.; Brosh R.; Buganim Y.; Goldfinger N.; Klocker H.; Schalken J.A.S; Rotter V. 2009. Prostate stromal cells produce CXCL-1, CXCL-2, CXCL-3 and IL-8 in response to epitheliasecreted

IL-1.

Carcinogenesis; 30: 698-705

22. Matsuo Y.; Ochi N.; Sawai H.; Yasuda A.; Takahashi H.;
Funahashi H.; Takeyama H.; Tong Z.; Guha S. 2009. CXCL8/IL-8 and CXCL12/SDF-1alpha cooperatively promote invasiveness and angiogenesis in pancreatic cancer. Int J Cancer ; 124:853-861

23. Lane D.; Matte I.; Claudine Rancourt C. and Piché A. 2011.Prognostic significance of IL-6 and IL-8 ascites levels in ovarian cancer patientsBMC Cancer, 11:210

24. Greg P. Bertenshaw, Ping Yip; Partha Seshaiah. 2008. Multianalyte Profiling of Serum Antigens and Autoimmune and Infectious Disease Molecules to Identify Biomarkers Dysregulated in Epithelial Ovarian Cancer. Cancer Epidemiol Biomarkers Prev ,17:2872-2881.

25. Fasciani A.; D'Ambrogio G.; Bocci G.; Luisi S.; Artini P.G.; Genazzani A.R.2001. VEGF and IL-8 in ovarian cystic .pathology. Fertil Steril , 75, 6, 1218-1221. 


\section{المستويات المصلية لعامل نمو البطانة الوعائي والانترلوكين 8 كمعلمات حيوية جديدة للتشخيص المبكر لأورام المبيض والترليض}

خالا عبد الرزاق حبيب* ميساء غازي جمعة

**ن منذر جفر حسين

جامعة ميسان- كلية الطب.

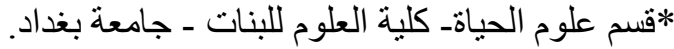
|** الكلية الملكية - وحدة الكبد- لندن.

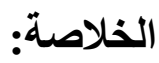

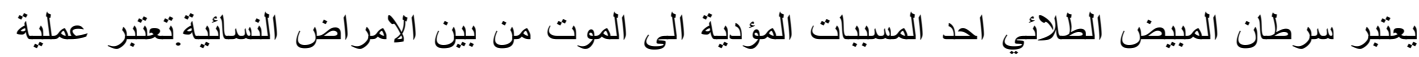

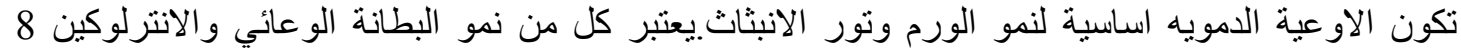

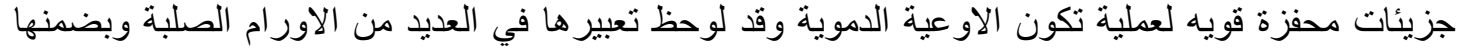

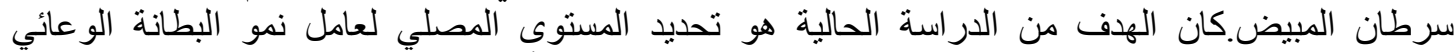

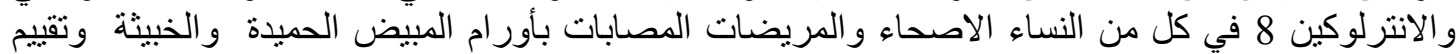

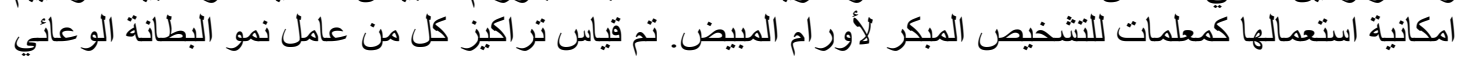

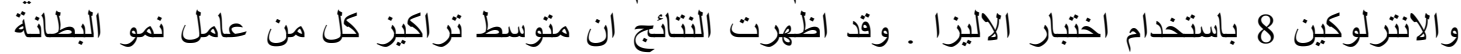

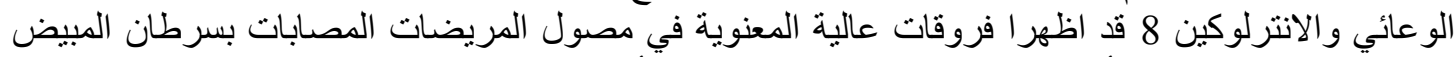

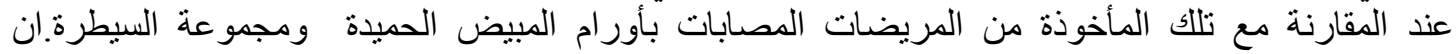
المستويات المصلية لعامل نمو البطانة الوعائي والانترلوكين 8 ربما تعتبر كوسائل الضافية في تمييز المئية الورام المبيض. الكلمات المفتاحية: سرطان المبيض، عامل البطانة الو عائي، الانترلوكين 8 ، مصل الدم. 